\title{
Determining the Relationship between the Items of the Cash Flow Statement with Abnormal Output in the Companies Enlisted in Stock Exchange Organization
}

Fatemeh Haftlang Mohammadjani (Haftlang f@yahoo.com)

Campus of Accounting and Management of the Islamic Azad University

Dr. Hassan Ghodrati (Corresponding Author)

Campus of Accounting and Management of the Islamic Azad University

Dr. Hossein Jabbari

Campus of Accounting and Management of the Islamic Azad University

\begin{abstract}
The continuity of the operations, growth or decrease in the business activities of any company is in line with the on time and optimized funding of cash liquidity and suitable as well as the proper use of them in investment paths in the direction of creating output and ultimately, to increase the shareholders' wealth. The goal of this research is to determine the relationship between cash liquidity and abnormal output of stocks. For this purpose, 130 companies were selected by employing simple random method among the companies were enlisted in Stock Exchange Organization. Different cash liquidities included the operational and non-operational cash flows were taken as the five main independent variables, the divisible profits, financial leverage and the size of the company were defined as other independent variables; and, the abnormal output of stock was considered as dependent variable. After analyzing the pre-hypothesis by using combined multi-variable regression and based on the panel data analysis, five linear relations were assessed. The results of the research showed positive relationship between different cash flows, except tax cash flow and the abnormal output of stock. With respect to the determining coefficients which were obtained, the assessed relationship was considered very weak linear relation. The results of T.Student and Fischer showed that the assessed relationship was not significant in the statistical society level. Analyzing the non-parametric correlation showed similar results.
\end{abstract}

Keywords: Cash flows, abnormal output of stocks, operational, non-operational

\section{Council for Innovative Research}

Peer Review Research Publishing System

\section{Journal: Journal of Social Sciences Research}

Vol. 5, No. 3

Jssreditor.cir@gmail.com

www.jssronline.com 


\section{Introduction}

One of the characteristics of an efficient market in its strong shape is that the stock price in each given moment of time reflects the intrinsic value of the stock with respect to the existing and relevant data in the market and there is no abnormal output in such market. Decreasing this additional output; too, is possible only through identifying the factors that are involved in its emergence. Based on the researches which have been carried out so far, there is a relationship between the abnormal output and a number of financial information which is released. The information related to cash flows is one of the most important data in different decision making models adopted by investors and other users of the financial information; and, the rate of capital output/return is the major factor which is considered by any investor in his decision making procedure. That is, investors seek the highest output opportunities for investing their extra sources in the capital markets. On the other hand, there have been so far many efforts on presenting a model in predicting the output of stockswhich is one of the interested topics of investors and financial researchers that could predict the stock output in a reliable context. (Axo 2003)

Until 1990s, the assumption was that the capital assets pricing model was a flawless model for predicting stocks output; however, the results of the researches showed that the model did not have sufficient capabilities in predicting the stocks output. As the model lost its creditability, many efforts were made to replace it with a model that could determine the stocks output in the best possible manner; nevertheless, to this date, the financial researchers have not reach an agreement on providing an alternate model (Triantis, 2008).

Presently, the investors are able to study the abnormal stocks output in some extent by creating a connection bridge between the stocks output and other accounting information (including the cash flow statement) provided that the accounting information is effective on the price; or in another word, the market is in strong level in terms of efficiency. The investors and financial statement users try to direct their financial sources to a direction that could contain the least risk and highest output; and on one hand, the final information in the market that show lack of transparency is the biggest concern of potential shareholders, and on the other hand, the holders of that information could attain an output higher than the ordinary output of the stocks. As it has been already noted, essentially, acquiring abnormal output is possible only when there is no clear and accurate information on the abnormal output (Teymouri, 2006).

This research studies the relationship between the items of cash flow statement and the abnormal output of stocks in the companies enlisted in the Stock Exchange Market of Tehran.

\section{History of Research:}

Ball and Brown (1968) studied the information content of profit. They showed that if informing the profit contains information contents, samples with changes in unanticipated profit will have positive average abnormal output rate on the announcement time and the samples with negative unanticipated profit changes; too, have average negative abnormal output (Watts and Zimmermann, 1986, Pp 39-46).

Boeschi (1997) studies the effects of abnormal outputs on fundamental analysis strategy. He showed that changes in the goods stocks, capital expenses and effective tax rates have good predictability in conditions when the market is in its lesser reaction state (Abarbanel and Boeschi, 1998, Pp 19-45).

Frette (1998) studies the relationship between the predicted profit and the value of the company; and, the abnormal output of stocks of those types of companies in the initial supply phase and concluded that the profit predictions in connection with the values of the companies were in the initial public supply and they are more effective than other tools such as accumulated profit; in addition, there is a significant positive relationship between the profit prediction error and the abnormal output.

Bartholdi (1998) studied the relationship between the changes in the ratio of profit to the price of stocks with additional output. The results of this research showed that the changes in the proportion of the profit of each stock to the price of each reported stock could be used for predicting the future outputs of the stock.

Sadjadi (1993) studied the relationship between unanticipated profit and the future abnormal output of the stocks of companies enlisted in the Stock Exchange Market of Tehran. The findings of his research showed positive significant relationship between the unanticipated changes in the profit and the future abnormal output of the stocks.

Bahramfar and Shams Alam (2003) studied the effects of accounting variables on the future abnormal outputs of the stocks of companies enlisted in Exchange Market of Tehran. The results of their research showed that the degree of financial leverage, investment output rate, finance growth rate, operational cash liquidity, cost of interests and divisible profit are effective on the abnormal output of stocks.

Neslihan (2004) studied the contents of the effects of size, ration of book value to market value and past information on the abnormal output. The results of this research showed that the financial statements released by the companies have informative contents. In addition the observed abnormal outputs do not appear merely due to high risk or mistaken market pricing in the market; but, the size of the company could also be determinant factor in this relations.

Mark, Scott and Richard (2006) in their research titled the relationship between financial funding activities on the prediction of analyzers and the stocks output in a 30 -year old period concluded that there was a reverse relationship 
between net cash flow of each class of funding activities with the stocks output as well as the company's profitability. The innovative aspect of this research was using cash flow for the information acquired from financing and in that respect, it had a fully cash perspective on the subject of the discussion without considering other items of changes in the capital structure such as increasing the capital through collecting the claims, increase in capital from accumulated profits and reserves and converting liability to the capital. In this research, both hypothesis of inaccurate pricing and wealth transfer were tested simultaneously.

Hashemi (2007) studies the abnormality of the subscribed items in the condition of financial inability risk. He showed that the reverse and significant relationship between the subscribed items and future abnormal output of the stocks showed the existence of abnormality in the subscribed items in Exchange Market of Tehran. In addition, he found that even after adding the financial inability risk variable to the research model; there still existed a significant and reverse relation between the subscribed items and the future abnormal output of stocks; however, the certainty level of this relation decreased by considering the variable of financial inability risk.

Yang, Qu and Kim (2007) studied the relationship between abnormal output with financial methods and size. They showed that the hosts prior to emergence received abnormal positive output for 12 months and there was a negative relationship between the cash payments and the abnormal output of service recipients.

Gamba \& Triantis (2008) studied the effect of size of the company on the tests statistic based on abnormal output in accordance with the market model methods and the modified output of the market in small markets. By using simulation, they concluded that the abnormal output is higher in large companies than smaller companies.

Martens \& Wincop (2008) studied the relationship between the capability of predicting the abnormal output and anticipated errors. They showed that in markets with high capabilities in the abnormal outputs, the predictability on the output errors is higher with similar degrees. The same is true on other markets.

Kousha (2009) studied the relationship between abnormal output and the financial information which is released at the Exchange Market of Tehran. He showed that the abnormal output could be affected by the financial information of the companies. Few investors were enabled to calculate the anticipated output rate by using a number of financial ratios. This information is not reflected in the real price of the stocks and led to the establishment of additional output for the group of investors who were aware of such relations.

Lashgari (2009) studied the relationship between the debt ratios and the selected items in cash flow statement. He showed there were significant relationship between the proportion of current debts to the shareholders' liabilities, the current debt to the total assets, long-term debts to the shareholders' equity, long-term debt to total assets, the total debts to total assets, total debt to the shareholders' equity; and the selected items of cash flow statement and among the ratios planned, there is a positive and significant effect between the long-term debt to shareholders' equity with operational cash flows acquired or consumed, the investment and financing activities.

Li (2009) in a research titled "Relationship between Distribution of Cash to price (t/p) and the output of share market showed that the $t / p$ index had a better perspective in distributing cash to the divisible profit index.

Khani and Pour Heydari (2001) studied the relationship between accounting profit and the abnormal output of stocks in the Exchange Market of Tehran. Based on the findings of the research, on the date of declaring the profit and in the time period of the research, the abnormal output performance index intensively increases in average for the sum of the sample companies which were selected (Jahani, 2007, Pp 1-32).

Chauvin et al (2012) studied the effects of the items of the three-stage cash flow on maintaining cash during 1988 2009. The results showed that the final value obtained through the operational activities was higher than the other two items and the main amount of cash kept in the company was the result of the cash acquired through operational activities. In another word, the cash resulted from operational activities had positive and significant relationship with maintaining cash and had higher coefficient than in the two items.

Cohen and Thomas (2012) studied the relationship between the financing activities and the subscribed accounts and stocks output; and the result of the research revealed the existence of negative relationship between the financing operations and stocks output.

Vadiei and Hosseini (2012) studied the relationship between abnormal output of stocks and the assessment criteria of the performance of Exchange Market of Tehran. They showed that among all criteria of performance assessment, the significant relationship exists only between the current ration, immediate ratio, percent of debts to the total assets, the percentage of the output of sum of assets, the percent of profit to the gross profit, the percent of operational profit to the income, the percent of gross profit to the income and the ratio of $p / B, p / E$ and the abnormal output of stocks.

Rezazadeh (2013) studies the factors in the continuity of the abnormal output of the stocks after declaring the profit. For this purpose, after declaring the profit, the reaction of small and large investors to the unanticipated profits based on random pattern and the predicted model of profit were studied; respectively. The findings of the research showed that the 
small investors perform transactions in the direction of unanticipated profits based on random step model and the large investors deal based on the prediction model for unanticipated profits.

Bayat (2013) studied the theoretical fundamentals of the relationship between abnormal output of stocks and the informative contents of cash flow. They explained that the cash flow statement could provide important information on the values, reasons and time intervals between the profit, receipt and payment of cash. In addition, the investors use information related to cash flow for predicting annual output of stocks, particularly the abnormal output of stocks, which have significant importance in the decision making.

Hassanzadeh (2013) studied the effective factors on the short-term abnormal output of the newly enlisted companies at Exchange Market of Tehran. Studying the hypothesis of research by using regression analysis and the oneside variance analysis showed that among different factors, there was only the type of industry which affected the shortterm abnormal output.

Magina (2013) in a research studied the relationship between the cash which was maintained, the circulating capital and the value of company and the abnormal output in the Stock Exchange Market of France. The results of the research showed positive and significant relationship between the maintained cash, accounting profit and the divisible profit on the abnormal output; however, there was a negative and significant relationship between financial leverage, market leverage, the cost of interest and net assets and the abnormal output.

Vencata (2013) studied the effects of lowered quality of profit on the fluctuations of abnormal output of stocks in the United States. They used the two indexes of average variance of monthly crude outputs and average monthly additional output for measuring the fluctuations of stock output. The used the two models Dicho and Dicho (2010) and square root abnormal subscribed items based on the modified model.

Saghafi and Sarraf (2014) studied the future cash flow prediction model. Their findings in the research revealed that the random step model has a better ability in predicting operational cash flow in comparison with the better judgment base model; on the other hand, the results obtained from companies with government influence showed that subscribed model is more suitable in assessing the future cash flow.

\section{Research hypothesis:}

The present research is carried out in testing two major hypotheses as follows:

\section{Main hypothesis:}

There exists relationship between the items in cash flow statement and the abnormal output of stocks in the companies enlisted in Stock Exchange Market of Tehran.

Secondary hypothesis:

1- There is a relationship between the cash flow of operational activities and abnormal output of stocks.

2- There is a relationship between the cash flow of the output and the profit payable for the stocks; and the abnormal output of the stocks.

3- There is a relationship between the cash flow of income tax and abnormal output of stocks

4- There is a relationship between the cash flow of investment activities and abnormal output of stocks

5- There is a relationship between the cash flow of financing activities and abnormal output of stocks.

\section{Research methodology}

The present research is applied in terms of goal and the post-event research plan has been used as it benefitted from the historical data for the research. In terms of methodology, it is inferential and because of using random sampling, it is descriptive- inductive.

\section{A) Statistical society of the research and taking sample:}

The statistical society of the research consists of enlisted companies in stock exchange market which were not financial middleman or investors and is defined within the scope the information of which had been accessible. 130 companies were selected at random and their performance within the time interval of 2008-2013 has been assessed and evaluated.

\section{B) Analysis method:}

In this research, following statistical methods have been used for describing or analyzing data:

1)Descriptive methods: In line with describing the statistical samples and findings of the research, the average parameters calculation, variance, criteria deviation and using the classification table and graphic diagrams are used. 
2)Pre-hypothesis analysis methods: Due to using combined linear regression, first, the pre-hypothesis (presumptions) of this method was assessed. Thus, to assess normalization of independent and dependent variables distribution, the Kolmograph- Smirnov test was used and to select between the methods of panel data and combined data, the F. Limmer test was used. To identify if the differences in cross session units were fixed or random, Hassman test statistic; for inconsistency of variances, the White Test, and for testing the independence of errors or absence of autocorrelation among independent variables, the Durbin- Watson test were used.

3)Analysis of the relationship between variables: To analyze the relationship among variables, the combined linear regression method, and to generalize the parameters to concerned society in the model and for determining the relations, the $t$ statistic and $F$ statistic were used.

\section{C) Research model}

In this research, the relationship among variables of the research has been defined in the template of following general relation:

$$
\begin{aligned}
& Y 1=f(x 1, x 6, x 7, x 8) \\
& Y 2=f(x 2, x 6, x 7, x 8) \\
& Y 3=f(x 3, x 6, x 7, x 8) \\
& Y 4=f(x 4, x 6, x 7, x 8) \\
& Y 5=f(x 5, x 6, x 7, X 8)
\end{aligned}
$$

\begin{tabular}{|c|c|c|c|c|}
\hline No. & $\begin{array}{l}\text { Mathematica } \\
\text { I symbol }\end{array}$ & $\begin{array}{l}\text { Abbreviation } \\
\text { Symbol }\end{array}$ & Definition of variables & Type of variables \\
\hline 1 & $\mathrm{Y}$ & $A R_{i}$ & Abnormal stock output & Dependent variable \\
\hline 2 & $X 1$ & CFO & $\begin{array}{l}\text { Cash flow of operational } \\
\text { activities }\end{array}$ & $\begin{array}{l}\text { Independent } \\
\text { variable }\end{array}$ \\
\hline 3 & $X 2$ & CFR & $\begin{array}{l}\text { Cash flow of output activities } \\
\text { and commission fee }\end{array}$ & $\begin{array}{l}\text { Independent } \\
\text { variable }\end{array}$ \\
\hline 4 & X3 & CFT & Cash flow of income tax & $\begin{array}{l}\text { Independent } \\
\text { variable }\end{array}$ \\
\hline 5 & $X 4$ & CFI & $\begin{array}{l}\text { Cash flow of investment } \\
\text { activities }\end{array}$ & $\begin{array}{l}\text { Independent } \\
\text { variable }\end{array}$ \\
\hline 6 & $X 5$ & CFF & Cash flow of financial provision & $\begin{array}{l}\text { Independent } \\
\text { variable }\end{array}$ \\
\hline 7 & $X 6$ & DIV & $\begin{array}{l}\text { Divisible profit (dividends of } \\
\text { stocks payable) }\end{array}$ & $\begin{array}{l}\text { Independent } \\
\text { variable }\end{array}$ \\
\hline 8 & $X 7$ & $L E V L$ & Financial leverage degree & $\begin{array}{l}\text { Independent } \\
\text { variable }\end{array}$ \\
\hline 9 & X8 & $S I Z E$ & Size of company & $\begin{array}{l}\text { Independent } \\
\text { variable }\end{array}$ \\
\hline
\end{tabular}

Variables that are used in these relations are defined in table number 1 :

Table 3-1- Definition of variables

In the present research, the abnormal stocks output as one of the profitability scale is considered as dependent variable and different cash flows as scales of circulating capital management constitute the main independent variables. In this research, along with main independent variables, the variables of the size of company, financial leverage and divisible profit have been taken as effective variables. 
To determine the relationship among variables, based on researchers of Falkner and Wang (2006), Dittmer and Mart Smith (2007), Jung and Kim (2009), Deniz and Silicov (2010) and Ben Rochen et al (2013), five linear relations were used as follows which are assessed by using combined linear regression and panel data analysis.

1) $A R_{i, t}=\beta_{0}+\beta_{1} C F O_{i, t}+\beta_{6} \operatorname{DIV}_{i, t}+\beta_{7} L_{i, t}+\beta_{8} S I Z E_{i, t}$

2) $A R_{i, t}=\beta_{0}+\beta_{2} C F R_{i, t}+\beta_{6} \operatorname{DIV}_{i, t}+\beta_{7} L_{i, t}+\beta_{8} \operatorname{SIZE}_{i, t}$

3) $A R_{i, t}=\beta_{0}+\beta_{3} \mathrm{CFT}_{i, t}+\beta_{6} \mathrm{DIV}_{\mathrm{i}, \mathrm{t}}+\beta_{7} \mathrm{~L}_{\mathrm{i}, \mathrm{t}}+\beta_{8} \mathrm{SIZE}_{\mathrm{i}, \mathrm{t}}$

4) $A R_{i, t}=\beta_{0}+\beta_{4} C F I_{i, t}+\beta_{6} D_{I V}+{ }_{i, t}+\beta_{7} L_{i, t}+\beta_{8} S E_{i, t}$

5) $\quad A R_{i, t}=\beta_{0}+\beta_{5} \mathrm{CFF}_{i, t}+\beta_{6} \mathrm{DIV}_{\mathrm{i}, \mathrm{t}}+\beta_{7} \mathrm{~L}_{\mathrm{i}, \mathrm{t}}+\beta_{8} \mathrm{SIZE}_{\mathrm{i}, \mathrm{t}}$

\section{5) Findings of the research:}

In this part of paper, the data description, pre-assumptions- hypothesis analysis and ultimately, analysis of the relationship among variables and generalizing that test to those variables are discussed.

\section{A) Description of findings:}

The results of describing the findings are listed in table number 2. In this table, the descriptive statistics of the variables of the research has been calculated.

Table number 2: Description of the findings of the research

\begin{tabular}{|c|c|c|c|c|c|c|}
\hline Description & Minimum & Maximum & Average & $\begin{array}{c}\text { Criteria } \\
\text { deviation }\end{array}$ & $\begin{array}{c}\text { Skewness } \\
\text { coefficient }\end{array}$ & $\begin{array}{c}\text { Stretch } \\
\text { coefficient }\end{array}$ \\
\hline$A R_{i, t}$ & 0.00 & 21.57 & 1.2763 & 2.18780 & 4.352 & 24.996 \\
\hline$C F O$ & 1.40 & 4186508 & 48324 & 209441 & 12.318 & 209.161 \\
\hline$C F R$ & 0.00 & 1158651 & 31154 & 118875 & 6.382 & 42.851 \\
\hline$C F T$ & 0.00 & 11592589 & 160716 & 823042 & 10.074 & 118.811 \\
\hline$C F I$ & 12.75 & 3863053 & 32973 & 202138 & 13.650 & 214.046 \\
\hline$C F F$ & 0.00 & 2282668 & 23374 & 133025 & 13.169 & 193.674 \\
\hline$D I V$ & 0.00 & 4200000 & 148058 & 411520 & 5.410 & 34.732 \\
\hline$L E V L$ & 0.00 & 1.00 & .6551 & .17552 & -.667 & .687 \\
\hline$S I Z E$ & 2.89 & 8.65 & 5.79 & .64 & .472 & 2.526 \\
\hline
\end{tabular}

\section{B) Analysis of the relationship among variables}

In this part, due to the establishment of hypothesis of using combined linear regression, consequent to the similar or related researches to determine the relationship between the dependent variable, "the abnormal stock output" is used as profitability scale with main variables, different cash flows and other independent variables consisting divisible profit, financial leverage and size of company. 


\section{6) Relationship between abnormal stocks output and operational cash flow:}

This mathematical relation in the research model was defined as the first relations. The statistical software of Panel Data analysis and combined linear regression are used to determine the relationship between variables. Table number 3 summarizes the results of regression parameters assessment in expressing the relationship among variables:

Table 3: Relationship between Operational Cash Flow and Divisible Profit

\begin{tabular}{|l|c|c|c|c|c|c|}
\hline Description & Symbol & Coefficient & $\begin{array}{l}\text { Criteria } \\
\text { deviation }\end{array}$ & $\begin{array}{l}\text { Standard } \\
\text { coefficient }\end{array}$ & $\begin{array}{l}\text { Statistic } \\
\text { T }\end{array}$ & $\begin{array}{l}\text { Significance } \\
\text { level }\end{array}$ \\
\hline $\begin{array}{l}\text { Width from } \\
\text { origin }\end{array}$ & --- & 0.1235 & 0.0125 & 0.0000 & 0.897 & 0.587 \\
\hline $\begin{array}{l}\text { Financing } \\
\text { cash }\end{array}$ & CFO & $-1.468 \mathrm{E}-07$ & .000 & -.014 & -.391 & .696 \\
\hline $\begin{array}{l}\text { Distributable } \\
\text { dividends }\end{array}$ & Div & $-1.710 \mathrm{E}-07$ & .000 & -.032 & -.749 & .454 \\
\hline $\begin{array}{l}\text { Financial } \\
\text { leverage } \\
\text { degree }\end{array}$ & LEV & .183 & .466 & .015 & .392 & .695 \\
\hline $\begin{array}{l}\text { Size of } \\
\text { company }\end{array}$ & Size & .111 & .147 & .032 & .755 & .450 \\
\hline
\end{tabular}

If the parameters assessed in table number 3 are placed in the parametric linear relation of first relation in research model, the mathematical relation between variables is changed into a linear equation as follows:

1) $\quad \mathrm{AR}_{\mathrm{i}, \mathrm{t}}=0.1235-0.00000015 \mathrm{CFO}_{\mathrm{i}, \mathrm{t}}-0.00000017 \mathrm{DIV}_{\mathrm{i}, \mathrm{t}}+0.183 \mathrm{LEV}_{\mathrm{i}, \mathrm{t}}+0.111 \mathrm{SIZE}_{\mathrm{i}, \mathrm{t}}$

Based on the assessments performed, the results showed that:

One) With respect to negative slope of variables, the relationship between abnormal stocks output with operational cash flow, and the divisible profit was reversed. In another word, increase in the operational cash flow and the amount of divisible profit is accompanied with decrease in abnormal stocks output.

Two) Due to positive slope of variables, the relationship among the abnormal stock output with operational leverage, and the size of company is positive and in another word, the larger and more central companies have higher abnormal stocks output.

Three)The determining coefficient was 0.0028 and its modified value in standard state or omission of the width from origin is equal to 0.0012 , that showed less than one percent of counter changes among independent variables and a function is expressed by assessed relations, and there is a "very weak linear relation" between the dependent variable of abnormal stock output as profitability scale with the variables of operational cash flow, divisible profit, financial leverage and size of the company as independent variables.

Four) The significance levels based on the results of T. Student test are equal to $0.587,0.690,0.454,0.695$ and 0.450 ; respectively. In all cases, the calculated coefficients were more than one and five percents and the linear relationship among variables are rejected. Therefore, with respect to the small size and inclination of determining coefficient toward zero, there is a very weak liner relationship between independent and functional variables; which, this relation was very weak in 95 and 99 percent certainly level could not be generalized to statistical society or stock exchange market companies.

As the linear relationship was not significant and absence of some of the hypothesis/presuppositions of this relations, in this part, the relationship among those ratios and the economic value added are measured in classified and nonparametric. The results showed that there is a reverse relationship between the abnormal output of stock and the operational cash flow and divisible profit. Since the mentioned coefficients trend to zero, this relationship is very weak and ultimately, due to the more significance level and its being more than 5 percent, the hypothesis zero is accepted and the relationship between abnormal output of stocks with the operational cash flow and divisible profit are rejected. 
The relationship between abnormal output of stocks and cash flow of financial income:

This mathematical relation in the research model was defined as the second relations and the assessments and relevant analysis are summarized in table number 4 :

Table 4: Assessment of the parameters of third relations

\begin{tabular}{|l|c|c|c|c|c|c|}
\hline Description & Symbol & Coefficient & $\begin{array}{l}\text { Criteria } \\
\text { deviation }\end{array}$ & $\begin{array}{l}\text { Standard } \\
\text { coefficient }\end{array}$ & $\begin{array}{l}\text { Statistic } \\
\text { T }\end{array}$ & $\begin{array}{l}\text { Significance } \\
\text { level }\end{array}$ \\
\hline $\begin{array}{l}\text { Width from } \\
\text { origin }\end{array}$ & --- & 0.1875 & 0.2125 & 0.0000 & 0.812 & 0.645 \\
\hline $\begin{array}{l}\text { Financing } \\
\text { cash }\end{array}$ & CFR & $-5.826 \mathrm{E}-08$ & .000 & -.022 & -.610 & .542 \\
\hline $\begin{array}{l}\text { Distributable } \\
\text { dividends }\end{array}$ & DIV & $-1.735 \mathrm{E}-07$ & .000 & -.033 & -.760 & .447 \\
\hline $\begin{array}{l}\text { Financial } \\
\text { leverage } \\
\text { degree }\end{array}$ & LEV & .181 & .466 & .015 & .389 & .697 \\
\hline $\begin{array}{l}\text { Size of } \\
\text { company }\end{array}$ & Size & .112 & .147 & .033 & .765 & .445 \\
\hline
\end{tabular}

If the assessment parameters in table 4 are replaced in the second parametric linear relationship of the research model, it changes as follows:

2) $\quad \mathrm{AR}_{\mathrm{i}, \mathrm{t}}=0.1875-0.00000006 \mathrm{CFR}_{\mathrm{i}, \mathrm{t}}-0.00000017 \mathrm{DIV}_{\mathrm{i}, \mathrm{t}}+0.181 \mathrm{LEV}_{\mathrm{i}, \mathrm{t}}+0.112 \mathrm{SIZE} \mathrm{E}_{\mathrm{i}, \mathrm{t}}$

Based on the assessments performed, it could be concluded that:

One) Due to negative slope of variables, the relationship between the abnormal output of stocks and the cash flow of financial income, and the divisible profit is reverse and in another word, increase in the operational cash flow and amount of divisible profit is accompanied with decrease in abnormal output of stocks.

Two) With respect to positive slope of variables, the relationship between the abnormal output of stocks with the operational leverage and the size of company is direct and in another word, the larger and more core companies have higher abnormal stocks output.

Three) The determining factor is equal to 0.0034 and its modified value in standard state is 0.0021 , showing that less than one percent of counter changes among independent and functional variables is expressed by assessed relations. As a result, there was "a very weak linear relation" between the variables.

Four) The significance levels have been calculated based on the results of $T$. students as $0.645,0.542,0.447,0.697$ and 0.445. In all cases, the coefficients that are calculated were more than one and five percent and as it is shown in previous sections, the linear relationship between variables is rejected. Therefore, with respect to the small size of the determining coefficient and its inclination to zero, there is a very weak linear relationship in the independent and functional variables and this very weak relationship in 95 and 99 percent certainly level could not be generalized in statistical society or companies enlisted in stock exchange market.

In non-parametric analysis which is performed, with respect to the negative sign of Spearman Correlation coefficient, there is a reverse relationship between abnormal output of stocks and the cash flow of financial income and divisible profit. And, since the mentioned coefficients incline to zero, that relationship is very weak. Ultimately with respect to the significance level and its being larger than 5 percent, the hypothesis zero is accepted and the relationship between abnormal output of stocks and operational cash flow and divisible profit is rejected.

3) Relationship between abnormal output of stocks and tax cash flow: This mathematical relationship in the research model was defined as third relations and its regression assessments are summarized in table number 5 : 
Table 5: Assessment of the parameters of third relations

\begin{tabular}{|l|c|c|c|c|c|c|}
\hline Description & Symbol & Coefficient & $\begin{array}{l}\text { Criteria } \\
\text { deviation }\end{array}$ & $\begin{array}{l}\text { Standard } \\
\text { coefficient }\end{array}$ & $\begin{array}{l}\text { Statistic } \\
\text { T }\end{array}$ & $\begin{array}{l}\text { Significance } \\
\text { level }\end{array}$ \\
\hline $\begin{array}{l}\text { Width from } \\
\text { origin }\end{array}$ & --- & $7.994 \mathrm{E}-07$ & .000 & .043 & 1.209 & .227 \\
\hline $\begin{array}{l}\text { Financing } \\
\text { cash }\end{array}$ & CFT & $-1.568 \mathrm{E}-07$ & .000 & -.029 & -.687 & .492 \\
\hline $\begin{array}{l}\text { Distributable } \\
\text { dividends }\end{array}$ & DIV & .165 & .466 & .013 & .353 & .724 \\
\hline $\begin{array}{l}\text { Financial } \\
\text { leverage } \\
\text { degree }\end{array}$ & LEV & .111 & .147 & .032 & .754 & .451 \\
\hline $\begin{array}{l}\text { Size of } \\
\text { company }\end{array}$ & Size & $7.994 \mathrm{E}-07$ & .000 & .043 & 1.209 & .227 \\
\hline
\end{tabular}

If the assessment parameters in table 5 are replaced in the parametric linear relations, the third relation of research method will be in following shape:

3) $\mathrm{AR}_{\mathrm{i}, \mathrm{t}}=0.0000008-0.00000015 \mathrm{CFT}_{\mathrm{i}, \mathrm{t}}+0.165 \mathrm{DIV}_{\mathrm{i}, \mathrm{t}}+0.11 \mathrm{LEV}_{\mathrm{i}, \mathrm{t}}+0.0000008 \mathrm{SIZE}_{\mathrm{i}, \mathrm{t}}$

Based on the assessments performed, it could be concluded that:

One) With respect to negative slope of variables, the relationship between abnormal output of stocks and tax cash flow is reverse, in another word, increase in operational cash flow is accompanied with decrease in abnormal output of stocks.

Second) With respect to the positive slope of variables, the relationship between abnormal output of stocks with operational leverage, divisible profit and size of company is direct, in another word, the larger and more core companies and the enterprises that distributed higher profit had more abnormal output of stock.

Three) The determining coefficient is equal to 0.0024 and its modified value in standard state is 0.0013 , showing that less than one percent of variables changes are expressed by assessed relation. As the assessed determining factor inclines to zero, it could be concluded that there is a "very weak linear relation" between variables.

Four) The significance levels based on the results of T.Student test were $0.227,0.452,0.724,0.429$ and 0.227 and more than 5 percent; therefore, the linear relationship between variables is rejected. Therefore, with respect to the smallness and zero inclination of determinant coefficient, there exists a very weak linear relation between the independent and functional variables; and since this relationship is very week and could not be generalized in 95 and 99 percent certainly levels.

Five) The non-parametric analysis of relationship among variables by using Spearman Correlation analysis showed that due to negative sign of Spearman Correlation Coefficient, there is a revere relationship between the abnormal output of stocks and divisible profit. And since the mentioned coefficient inclines to zero, this relationship is very weak. Ultimately, due to the significance level and its being more than 5 percent, the hypothesis zero was accepted and the relationship between abnormal output of stocks and divisible profit is rejected.

4) Relationship between abnormal output of stocks and investment cash flow: This mathematical relation in the research model was defined as fourth relation and the relevant assessments are summarized in table number 6 : 


\begin{tabular}{|l|c|c|c|c|c|c|}
\hline Description & Symbol & Coefficient & $\begin{array}{l}\text { Criteria } \\
\text { deviation }\end{array}$ & $\begin{array}{l}\text { Standard } \\
\text { coefficient }\end{array}$ & $\begin{array}{l}\text { Statistic } \\
\text { T }\end{array}$ & $\begin{array}{l}\text { Significance } \\
\text { level }\end{array}$ \\
\hline $\begin{array}{l}\text { Width from } \\
\text { origin }\end{array}$ & --- & 0.12641 & 0.4521 & 0.000 & 1.1123 & 0.165 \\
\hline $\begin{array}{l}\text { Financing } \\
\text { cash }\end{array}$ & CFI & $-1.816 \mathrm{E}-07$ & .000 & -.017 & -.467 & .640 \\
\hline $\begin{array}{l}\text { Distributable } \\
\text { dividends }\end{array}$ & DIV & $-1.702 \mathrm{E}-07$ & .000 & -.032 & -.746 & .456 \\
\hline $\begin{array}{l}\text { Financial } \\
\text { leverage } \\
\text { degree }\end{array}$ & LEV & .180 & .466 & .014 & .387 & .699 \\
\hline $\begin{array}{l}\text { Size of } \\
\text { company }\end{array}$ & Size & .111 & .147 & .033 & .758 & .449 \\
\hline
\end{tabular}

By placing the parameters in table 6 , the linear equation of the relations among variables appear in following form:

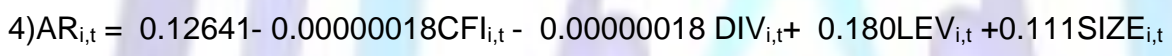

Analyzing the relationship among variables shows that:

One) The relationship between abnormal output of stocks with the investment cash flow and divisible profit is reverse and in another word, increase in investment cash flow and divisible profit is accompanied by decrease in abnormal output of stocks.

Two) With respect to the positive slope of variables, the relationship between the abnormal output of stocks with the operational leverage, and the size of company is positive and in another word, the larger and more indicative companies have higher abnormal output of stocks.

Three) The determining coefficient is 0.0026 and in standard status, it is 0.0013 , showing that less than one percent of counter changes of variables are expressed. As the assessed determining coefficient inclines to zero, one may conclude that a "very weak linear relation" existed between the dependent variable of abnormal output of stock as profitability measure with investment cash flow, divisible profit, financial leverage and size of the company as independent variables.

Four) The significant levels of $t$. Student test is equal to $0.0449,0.699,0.456,0.640$ and 0.165 ; respectively, more than one and five percent. Therefore, there is a very weak assessed relationship in 95 and 99 percent certainty, it could not be generalized to the statistical society or enlisted company in stock markets.

Five) The non-parametric analysis which was performed showed that as Spearman correlation coefficient is negative, there is a reverse relationship between the abnormal output of stocks with investment cash flow and divisible profit. And since the mentioned coefficient inclines to zero, that relationship is very weak. Ultimately, with respect to the significance level and its being larger than 5 percent, the hypothesis zero is accepted and the relationship between abnormal stock output with investment cash flow and divisible profit is rejected.

\section{3) Relationship between abnormal output of stock and financing cash flow:}

The estimation of parameters of this mathematical relation which is defined as fifth relation in the research model is summarized as per table 7 :

Table number 7: Assessment of the parameters of the fifth relationship 


\begin{tabular}{|l|c|c|c|c|c|c|}
\hline Description & Symbol & Coefficient & $\begin{array}{l}\text { Criteria } \\
\text { deviation }\end{array}$ & $\begin{array}{l}\text { Standard } \\
\text { coefficient }\end{array}$ & $\begin{array}{l}\text { Statistic } \\
\text { T }\end{array}$ & $\begin{array}{l}\text { Significance } \\
\text { level }\end{array}$ \\
\hline $\begin{array}{l}\text { Width from } \\
\text { origin }\end{array}$ & --- & 0.2002 & 0.1124 & 0.000 & 1.7524 & 0.098 \\
\hline $\begin{array}{l}\text { Financing } \\
\text { cash }\end{array}$ & CFF & $-4.785 E-07$ & .000 & -.029 & -.811 & .418 \\
\hline $\begin{array}{l}\text { Distributable } \\
\text { dividends }\end{array}$ & DIV & $-1.702 \mathrm{E}-07$ & .000 & -.032 & -.747 & .456 \\
\hline $\begin{array}{l}\text { Financial } \\
\text { leverage } \\
\text { degree }\end{array}$ & LEV & .189 & .466 & .015 & .405 & .686 \\
\hline $\begin{array}{l}\text { Size of } \\
\text { company }\end{array}$ & Size & .110 & .147 & .032 & .745 & .457 \\
\hline
\end{tabular}

By placing the parameters as assessed in table 7, the linear equations of the relationship among variables are changed as follows:

$$
\text { 5)AR } \mathrm{R}_{\mathrm{i}, \mathrm{t}}=0.2002-0.00000048 \mathrm{CFF}_{\mathrm{i}, \mathrm{t}}-0.00000017 \mathrm{DIV}_{\mathrm{i}, \mathrm{t}}+0.189 \mathrm{LEV}_{\mathrm{i}, \mathrm{t}}+0.110 \mathrm{SIZE}_{\mathrm{i}, \mathrm{t}}
$$

Based on the calculations and statistical analysis, it could be concluded that:

One) With respect to negative slope of variables, the relationship between the abnormal output of stocks and the investment cash flow, and the reverse profit is reversed. In another word, increase in the cash flow of investment and divisible profit is accompanied with reduction in the abnormal output of socks.

Two) The determining coefficient is 0.0020 and its modified value is equal to 0.0004 ; which showed that the assessed relations has expressed less than one percent of changes in variables. In conclusion "a very weak linear relation" exists between the dependent variable of abnormal stock output as the profitability scale with the variables of financial income cash flow, divisible profit, financial leverage and the size of the company as independent variables.

Three) Generalization of assessed linear relation: The significant levels in $t$. Student is equal to $0.098,0.418,0.456$, 0.686 and 0.457 ; respectively, and in all cases, it is more than one and five percents; thus, the linear relationship among variables has been rejected.

Four) The non-parametric analysis showed relationship between variables, which, with respect to the negative direction of Spearman Correlation Coefficient, there is a reverse relationship between abnormal output of stocks with financing cash flow and divisible profit. And, since the mentioned coefficient inclines to zero, this relationship is very weak. Ultimately, with respect to the significance level and being higher than 5 percent, the hypothesis zero is being accepted and the relationship between abnormal output of stocks with financing cash flow and divisible profit is rejected.

\section{Conclusion:}

The goal of this research is to assess the relationship between different types of cash flow as the main independent variable; and, the financial leverage, divisible profit and the size of company as other independent variables - which in most researches are considered as controlling variable- and the abnormal output of stock as dependent variable.

In this line, the financial reports by enforcing restrictions such as expiry of fiscal period at the end of the calendar year, accessibility of the 6- year financial reports in the time period under study from 2008 to 2013, non-belonging to the investment companies or financial dealership, the statistical society was defined as to consist 395 companies. Among those companies, 130 companies were selected at random and their historical performance data was obtained based on the financial reports presented to the stock exchange within a 6-year period of 2008 to 2013.

After describing the findings and analyzing the pre-hypothesis, the regression assessment was made on the relationship between variables by using combined linear regression. Based on the results of Kolmograph- Smirnov tests, White, Durbin Watson Consistency ad other suitable calculations and tests it was specified that the presumptions were established and it is possible to assess the relationship among variables by using combined liner regression method, subsequent to similar researches.

A combined linear regression relation was assessed as per each cash flow and based on it, it was shown that: 
1) Based on the negative coefficient of variables, there is a reverse relationship between the operational cash flows, financial income, investment and financing; and the abnormal output of the stocks

2) There is a direct relation between tax cash flow, financial leverage, divisible profit and size of the company, with the abnormal output of stocks.

3) With respect to the

4) With respect to the coefficient of determining the assessed mathematical relations that shifted to the zero in all items, there is a very weak linear relationship between the abnormal output of sticks as dependent variable and the operational cash flows; and, other independent variables.

5) As the significance level in T. Student and Fischer is bigger than 5 percent, there is a very weak linear relationship is assessed between variables in 95 percent certainty, it can not be generalized in statistical society and in another word, it is not significant. With respect to defining the research hypothesis based on the relationship among variables and rejection of liner relationship as described above, Spearman Non-parametric correlation analysis was used as well. The results of the assessments and significance levels that show consistency in the results of combined linear regression analysis and non-parametric correlation, the results which are obtained through table 8 is summarized as follows:

Table number 8: Sum-up of the Results of Relationship among Variables

\begin{tabular}{|l|l|l|}
\hline $\begin{array}{c}\text { Type of the relationship } \\
\text { subject of assessment }\end{array}$ & \multicolumn{1}{|c|}{$\begin{array}{c}\text { Statistical } \\
\text { Judgment }\end{array}$} & \multicolumn{1}{c|}{ Conclusion } \\
\hline $\begin{array}{l}\text { The abnormal output of stocks } \\
\text { and operational cash flow }\end{array}$ & $\begin{array}{l}\text { Acceptance of } \\
\text { hypothesis HO }\end{array}$ & $\begin{array}{l}\text { The hypothesis of } \\
\text { relationship among } \\
\text { variables is rejected. }\end{array}$ \\
\hline $\begin{array}{l}\text { The abnormal output of stocks } \\
\text { and Financial income cash flow }\end{array}$ & $\begin{array}{l}\text { Acceptance of } \\
\text { hypothesis HO }\end{array}$ & $\begin{array}{l}\text { The hypothesis of } \\
\text { relationship among } \\
\text { variables is rejected. }\end{array}$ \\
\hline $\begin{array}{l}\text { The abnormal output of stocks } \\
\text { and income tax cash flow }\end{array}$ & $\begin{array}{l}\text { Acceptance of } \\
\text { hypothesis HO }\end{array}$ & $\begin{array}{l}\text { The hypothesis of } \\
\text { relationship among } \\
\text { variables is rejected. }\end{array}$ \\
\hline $\begin{array}{l}\text { The abnormal output of stocks } \\
\text { and investment cash flow }\end{array}$ & $\begin{array}{l}\text { Acceptance of } \\
\text { hypothesis HO }\end{array}$ & $\begin{array}{l}\text { The hypothesis of } \\
\text { relationship among } \\
\text { variables is rejected. }\end{array}$ \\
\hline $\begin{array}{l}\text { The abnormal output of stocks } \\
\text { and the cash flow of funding }\end{array}$ & $\begin{array}{l}\text { Acceptance of } \\
\text { hypothesis HO }\end{array}$ & $\begin{array}{l}\text { The hypothesis of } \\
\text { relationship among } \\
\text { variables is rejected. }\end{array}$ \\
\hline $\begin{array}{l}\text { The abnormal output of stocks } \\
\text { and divisible profit, leverage, } \\
\text { size of the company }\end{array}$ & $\begin{array}{l}\text { Acceptance of } \\
\text { hypothesis HO }\end{array}$ & $\begin{array}{l}\text { The hypothesis of } \\
\text { relationship among } \\
\text { variables is rejected. }\end{array}$ \\
\hline
\end{tabular}

Resources and References 


\section{Persian sources}

1-Azar, E. Momeni, M, 2002, Statistics and its Application in Management (Statistical Analysis), $2^{\text {nd }}$. Vol. SAMT Publication

2-Bayat, Morteza, 2013, Study the Theoretical Fundamentals of the Relationship between the Abnormal Output of Stocks and the Information Context of Cash Flows, Master's Degree thesis, Modarres University

3-Bahramfar, N. Shams Alam, H, 2004, Study the Effects of Accounting Variables on the Abnormal Output of the stocks of the Companies Enlisted in Stock Exchange Organization of Tehran, The Accounting and Auditing Studies, Vol. 11, No 23$50: 3$

4-Teymouri, Habibollah (2006), Structure of Accounting Theory, Auditing Organization Publications

5-Saghafi, Ali \& Sarraf, Fatemeh, Hassas Yeganeh, Yahya and Amir, Maghsoud (2014), Study the Models of Predicting Future Cash Flow, Accounting and Management Auditing Publication

6-Hassanzadeh, Rasoul, 2013, Study the Effective Factors on the Short-term Abnormal Output of the Newly Enlisted Companies in SEO of Tehran, Master's Degree Thesis, I.A.U. Mahabad

7- Rezazadeh, Javad, 2013, Identification of the Effective Factors on the Continuity of the Abnormal Output of Stocks after Announcing the Profit in the Companies Enlisted in Stock Exchange of Tehran, Applied Researches and Financial Reporting, $2^{\text {nd }}$ Year, Spring and Summer 2013, Vol. 2, Pp. 7-22.

8-Sadjadi, S. 1998, Factors Effective on the Unanticipated Profit and its Relations with the Stock Price, The Accounting and Auditing Studies, Vol. 24: 34-60

9- Kousha, Kiana (2010), Abnormal Output, the Financial Information Released and their Relationship in the Companies Enlisted in the SEO Tehran, Master's Thesis, I.A.U. Central Tehran Campus

10-Lashgari, Zahra, 2010, Relationship between the Liability Proportions and Selective Items in Cash Flow Statements, Journal of Stock Exchange Market, $2^{\text {nd }}$ Year, Vol. 8, Pp 39-64

11-Hashemi, E, 2008, Study the Abnormality of the Subscribed Items in the Conditions of the Existence of the Financial Inability risks in the Companies Enlisted in Stock Exchange Market of Tehran, Master's Degree Thesis, Modarres University

12-Vadiei, M, Hosseini, S, 2012, The Relationship between the Criteria of Assessing the Criteria of of the Performance and the Abnormal Output of Stocks, Empirical Researches in Accounting, $1^{\text {st }}$ Year, Summer 2012, Vol 4: 73-87

\section{Non-Persian Resources}

13-Aksu,H. 2003. "The effect of size, book-to-market ratio and prior distress information on the market reaction to troubled debt restructuring announcements," Graduate School of Business, Koc University.

14-Ball, Ray and Philip Brown1968," An Empirical Evaluation of Accounting Income Numbers ", Journal of Accounting Research Autumu 1968,PP.159-78Bacchetta, P.

15-Mertens, E. \& Wincoop, E.V, (2008), "Predictability in financial. Journal of International Money and Finance, pp. 406426.

16-Bartholdy.J (1998) "Changes in earnings-price ratios and excess returns",International

17-Bushee , B. 1997. Abnormal Returns to a Fundamental Analysis Strategy, the Accounting Review ,73 , 19-45.

18- Firth, M., (1998), "IPO profit forecasts and their role in signaling firm value

and explaining post- listing returns", Applied Financial Economics, pp. 29-39. 86

19- Kim Mark, Richardson, Scoth and Sloan, Richard.2006. The relation between corporate financing activities, analysts' forcasts and stock returns", available at www.papers.ssrn.com.

20-Lee, C.K.M., Lau, H.C.W., Hob, G.T.S.and Ho, W. (2009). Design and development of agent-based procurement system to enhance business intelligence,Expert Systems with Applications 36:877-884.

21- Magyna.2013. in a study examining the relationship between cash holdings, capital and market value of firms with abnormal returns in France. International Accounting Standards Board.

22-Ozkan Neslihan.2004. "Corporate cash holdings: An empirical investigation of UK companies" Journal of Banking \& Finance 28: 2103-2134.

23-Venkata.2013. "The Determinants of Working Capital Management", The Journal of American Academy of Business,Cambridge, No.1، Vol10: pp. 149155.

24- kohen, D. Thomakos \& G. Papanastasopoulos .2012. "The Implications of Retained and Distributed Earnings for Future Profitability and Stock Returns", Review of Accounting and Finance, Vol 9: 395-423. 
25- Yang, J, Qu, H, \& Kim, W. 2007. Merger Abnormal returns and payment methods of hospitality firms. International Journal of Hospitality Management, 28: 579-585.

26-Gamba, A., \& Triantis, A. 2008. "The Value of Financial Flexibility". Journal of Finance, 63 (5) : 2263-2296.

27-Cohen, S.; Kaimenakis, N.; and G. Venieris (2012), "Reaping the Benefits of Two Worlds: An Exploratory Study of the Cash and

the Accrual Accounting Information

RolesinLocalGovernments",www.SSRN.com/sol3/Delivery.../SSRN_ID1693511_code376488.pdf , [13 July 2010]. 